\title{
Evaluation of Changing Pattern in Livestock Types in Sokoto-Rima River Basin, a Tropical Semi-Arid Region of Nigeria
}

\author{
${ }^{* 1}$ ADEJUWON, JO; ${ }^{2}$ ODUSANYA, AE; ${ }^{1}$ ADEKITAN, AA
}

\author{
Department of Water Resources Management and Agrometeorology, Federal University of Agriculture, Abeokuta \\ ${ }^{2}$ Institute for Hydrology and Water Management, University of Natural Resources and Life Sciences, Vienna (BOKU), 1190 Vienna, Austria \\ *Corresponding Author Email: adejoseph2003@yahoo.com
}

\begin{abstract}
The study examined the changing pattern in livestock types in Sokoto Rima-River Basin, semi-arid Nigeria. Clustered sampling technique was used to administer questionnaire to 450 respondents from 15 agricultural settlements in 15 Local Government Areas in the basin. Data were analyzed using frequency counts, percentages and pairwise t-test. Seventy-one percent $(70.7 \%)$ of the farmers reared livestock in the 1970 s, out of which 10.2 to $13.6 \%$ reared only cattle, sheep and goats while the combination of cattle and sheep, cattle and goats, sheep and goats, and cattle, sheep and goats varied from 3.6 to $20.2 \%$. In the 2000 s, $80 \%$ of the farmers reared livestock, with a variation of 10.4 to $11.6 \%$ for cattle, sheep and goats only, and 2.9 to $26 \%$ for cattle and sheep, cattle and goats, sheep and goats and cattle, sheep and goats respectively. The total of 39.6 to $45 \%$ farmers in the basin reared cattle, sheep and goats in the 1970s while 44.7 to $55.1 \%$ reared it in 2000s. The rearing of cattle only, sheep and goats, and cattle, sheep and goats together increased by $0.2 \%$ to $6.6 \%$ while sheep only, goats only, cattle and sheep, and cattle and goats decreased by $0.3 \%$ to $2 \%$. The total cattle reared has increased by $5.1 \%$ over time, while that of sheep and goats increased by $10.1 \%$ and $11.4 \%$ respectively. Sheep are $2.4 \%$ more than goats and $10.4 \%$ more than cattle. Livestock rearing has increased by $9.3 \%$ during the study period. A pairwise t-test showed no significant difference between the livestock types in the 1970s and 2000s in the study period.
\end{abstract}

DOI: https://dx.doi.org/10.4314/jasem.v23i4.27

Copyright: Copyright (C) 2019 Adejuwon et al. This is an open access article distributed under the Creative Commons Attribution License (CCL), which permits unrestricted use, distribution, and reproduction in any medium, provided the original work is properly cited.

Dates: Received: 17 February 2019; Revised: 21 March 2019; Accepted 09 April 2019

Keywords: livestock, goat, sheep, cattle, Sokoto Rima River Basin

Livestock constitutes one of Africa's major economic resources and accounts for one-third of Nigeria's agricultural Gross Domestic Products. It produces meat, milk, and other products as well as income, employment, food, farm energy and manure, fuel, transport and revenue for the government through taxation and export earnings from hides and skins. Most poor African farmers depend on livestock which provides cash income through the sale of animals and its products; a form of savings through herd growth; and insurance through the sale of animals to provide immediate cash to deal with significant or unexpected expenditures especially when crop fail (Fafchamps et al., 1998; Seo and Mendelsohn, 2008; International Union for Conservation of Nature (IUCN), 2010; PicaCiamarra et al., 2011). Livestock system in the developing world is characterized by quick transformation due to urbanization and population expansion in the request for livestock products as income rises (Thornton et al 2007). They are adversely affected by the detrimental effects of extreme weather. Sejian (2013) reported that climatic extremes and seasonal fluctuations in herbage quantity and quality affect the well-being of livestock, lead to declines in production and reproduction efficiency. Heat stresses which result in a decrease in milk, meat production, reproductive efficiency and animal health are the most significant direct impact of climate change on livestock production. Koubkovam, et al. (2002) noted heat stress as one of the environmental variables affecting livestock production in many geographical locations around the globe. Parons et al. (2001) have argued that high temperatures may reduce feed intake, lower milk production, lead to energy deficits that may lower cow fertility, fitness and longevity. Climate change impacts on livestock are being witnessed all over the world, but developing nations like Nigeria are more vulnerable due to the dependence of about $70 \%$ of the population relying on this sector for livelihood. Livestock is a major component of agriculture and this sector provides sustainability and stability to the national economy by contributing to farm energy and food security (Singh et al., 2011). According to UNFCCC (2007), agricultural production including access to food in many African countries is severely compromised and this would further adversely affect food security and exacerbate malnutrition. 
In spite of the importance of livestock in supporting livelihood through the provision of multiple socioeconomic benefits, no study has been carried out on the changing pattern in livestock types in Sokoto-Rima River Basin, semi-arid Nigeria. This study intends to fill the gap created by the lack of literature in the study area. The study aimed at assessing the changing pattern in livestock types in the Sokoto-Rima River Basin, Nigeria.

\section{MATERIALS AND METHOD}

The Study Area: Sokoto-Rima River Basin is situated between latitude $10.8^{\circ} \mathrm{N}$ and $13.58^{\circ} \mathrm{N}$ and longitude $3.30^{\circ} \mathrm{E}$ and $7.13^{\circ} \mathrm{E}$ (Figure 1 . It is bounded by the Niger Republic to the north, Niger and Kaduna States to the south and southeast, the Benin Republic to the west and Katsina State to the east. Sokoto-Rima Basin experiences a tropical climate, governed by the Intertropical Discontinuity (ITD; Adejuwon, 2015).

The ITD marks the boundary line between two air masses - the tropical maritime (mT) air mass from the Atlantic Ocean and the dry tropical continental (cT) air mass from the Sahara Desert (Adejuwon, 2016). The prevailing air mass at a particular period has a strong influence on the climate.

The climate exhibits a definite and marked the wet and dry season. The mT dominates during the wet season while the cT air mass predominates during the dry season. The wet season is between May and September in the southern part and June to September in the north (Iliya and Kwabe, 2000; Mamman, 2000; Adejuwon, 2012a). Annual rainfall amount varied from about $1013 \mathrm{~mm}$ in the southern part to about 650 $\mathrm{mm}$ in the northern part and is single maxima in character (Adejuwon, 2018).

The rainfall decreases in both duration and amount from the south northward. High humidity is experienced in the wet season while low humidity is experienced in the dry season (Emielu, 2000). The dry and dust-laden northeast trade winds called 'Harmattan' that blow from the Sahara desert under cloudless but dusty conditions dominate the entire area during the first half of the dry season. This period is marked by very low temperatures and thick fog. The mean annual temperature range is between $5^{\circ} \mathrm{C}$ and $10^{\circ} \mathrm{C}$ while the mean annual temperature is $34.5^{\circ} \mathrm{C}$ (Emielu, 2000; Adejuwon, 2015).

The extremes diurnal and seasonal range is affected by seasonal and latitudinal variations. The highest temperatures are normally in the hot season, March to April while the minimum temperatures are usually recorded in January to February.

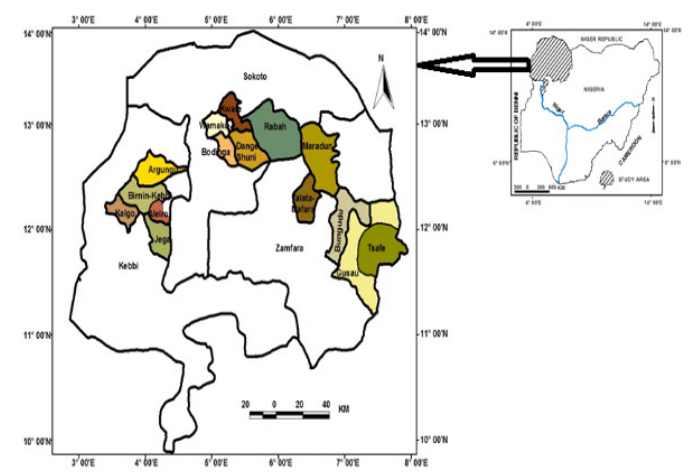

Fig 1: Selected local governments where the questionnaire was administered.

Data Collection and Analysis: Data for this study were obtained from primary sources. It was the result of field investigations, involving direct interaction with the respondents. The data were collected from farmers with structured questionnaires. Cluster sampling technique was used for the study. Five agricultural settlements from five Local Government Areas each from 3 zones of Sokoto, Kebbi and Zamfara states were selected for this study (Table 1). Thirty copies of questionnaires were administered to extract information on agricultural practices in each settlement, making a total of four hundred and fifty questionnaires. Data were analyzed using frequency counts, percentages and pairwise t-test.

Table 1: Locations of data collection in Sokoto-Rima River Basin

\begin{tabular}{cll}
\hline \multicolumn{1}{c}{ State } & Local Government & Communities \\
\hline Sokoto & Wamakko & Gumbi \\
& Bodinga & Mil Goma \\
& Kware & Durbawa \\
& Dange Shuni & Dange \\
& Rabah & Maikujera \\
& Kalgo & Kalgo \\
& Birni-Kebbi & Gulumbe \\
& Aliero & Dakala \\
& Jega & Basaura \\
& Argungu & Alwasa \\
& Talata Mafara & Tunfafiya \\
& Gusau & Madidi \\
& Maradun & Dosara \\
& Bungudu & Tazame \\
& Tsafe & Tsafe \\
\hline
\end{tabular}

\section{RESULT AND DISCUSSION}

Table 2 shows the seven categories of livestock reared in Sokoto-Rima River Basin. There are 360 (80\%) respondents' rearing livestock in Sokoto-Rima River Basin. in the River Basin (Table 2), Out of 318 $(70.7 \%)$ respondents that reared livestock in the $1970 \mathrm{~s}$, $10.2 \%$ to $13.6 \%$ reared only cattle, sheep and goats, $5.6 \%$ reared cattle and sheep, $3.6 \%$ reared cattle and goats, $5.6 \%$ reared sheep and goats while the remaining $20.2 \%$ reared cattle, sheep and goats. In the 2000 s, $80 \%$ of the farmers reared livestock, with a 
variation of 10.4 to $11.6 \%$ for cattle, sheep and goats only, $5.3 \%$ for cattle and sheep, $2.9 \%$ for cattle and goats, $12.2 \%$ for sheep and goats and $26 \%$ for cattle, sheep and goats together. Cattle, sheep and goats are the bulk of livestock and the major species of domesticated animals in Sokoto-Rima River Basin (Usman Danfodiyo University Consultancy Services (UDUCONSULT), 1990). Livestock rearing has increased by $9.3 \%$ over time in the study area. However, the increment does not apply to all categories of livestock reared. The number of farmers rearing cattle only, sheep and goats, and cattle, sheep and goats together increased by $0.2 \%$ to $6.6 \%$ (Table 3 ). Conversely, farmers rearing sheep only, goats only, cattle and sheep, and cattle and goats decreased slightly by $0.3 \%$ to $2 \%$. The increase in the number of farmers rearing the former categories resulted from increased farmer's personal interest in livestock rearing, influence from neighbours, income and more importantly by the increased awareness on the need of livestock dung to be used as manure as well as farmers increased interest in agropastoralism. The highest number of farmers rearing livestock in the River Basin raised the combination of cattle, sheep and goats together. Though some pastoralists don't rear goats, some reared goats with their herds. According to RIM (1992), Sahel goats are generally preferred by pastoralists in Nigeria. The goat is well adapted to its habitat, those environmental factors have little influence on the body weight, age at first conception, litter sizes and proclivity to year-round breeding (Wilson and Durkin, 1983; Wilson, 1987; Wilson and Sayers, 1987). The increase in the number of farmers rearing cattle only may have been caused by the increased need for cattle for ploughing and milking for family sustenance

Table 2: Type of livestock (Cattle sheep and goats) reared in the Sokoto-Rima River Basin

\begin{tabular}{|c|c|c|c|c|c|}
\hline \multirow[t]{2}{*}{$\mathbf{S} / \mathbf{N}$} & \multirow{2}{*}{ Type of livestock } & \multicolumn{2}{|c|}{ Reared in the 1970s } & \multicolumn{2}{|c|}{ Reared in 2000s } \\
\hline & & $\begin{array}{l}\text { Number of } \\
\text { respondents }\end{array}$ & Percentage & $\begin{array}{l}\text { Number of } \\
\text { respondents }\end{array}$ & Percentage \\
\hline 1 & Cattle only & 46 & 10.2 & 47 & 10.4 \\
\hline 2 & Sheep only & 61 & 13.6 & 52 & 11.6 \\
\hline 3 & Goats only & $t$ & 12.0 & 52 & 11.6 \\
\hline 4 & Cattle and sheep & 25 & 5.6 & 24 & 5.3 \\
\hline 5 & Cattle and Goats & 16 & 3.6 & 13 & 2.9 \\
\hline 6 & Sheep and Goats & 25 & 5.6 & 55 & 12.2 \\
\hline \multirow[t]{2}{*}{7} & Cattle, Sheep and Goats & 91 & 20.2 & 117 & 26.0 \\
\hline & Total & 318 & 70.7 & 360 & 80 \\
\hline
\end{tabular}

Table 3: Differences in the percentage in livestock types in the Sokoto-Rima River Basin

\begin{tabular}{llll}
\hline Type of livestock & $\begin{array}{l}\text { Percentage } \\
\text { in the 1970s }\end{array}$ & $\begin{array}{l}\text { Percentage } \\
\text { in the 2000s }\end{array}$ & $\begin{array}{l}\text { Difference } \\
(\%)\end{array}$ \\
\hline Cattle only & 10.2 & 10.4 & 0.2 \\
Sheep only & 13.6 & 11.6 & -2 \\
Goats only & 12.0 & 11.6 & -0.4 \\
Cattle and sheep & 5.6 & 5.3 & -0.3 \\
Cattle and Goats & 3.6 & 2.9 & -0.7 \\
Sheep and Goats & 5.6 & 12.2 & 6.6 \\
Cattle, Sheep and Goats & 20.2 & 26.0 & 5.8 \\
\hline
\end{tabular}

The sizable number of farmers reared cattle only, sheep only and goats only. Farmers usually rear them under village seasonality system of livestock farming. Cattle and goats were the least livestock reared in the River Basin. The decrease in the rearing of these latter categories was as a result of farmers shift to other categories.

They added a different livestock type (sheep, goats or cattle) to their herds, depending on the type they have before. It was discovered that some of the farmers rearing cattle and sheep, cattle and goats now rear cattle, sheep and goats while most of those rearing sheep only and goats only now rear sheep and goats. Generally, the total of 39.6 to $45 \%$ farmers in the River Basin reared cattle, sheep and goats in the 1970s while 44.7 to $55.1 \%$ reared it in the 2000 s (Table 4 ). The rearing of cattle has increased by $5.1 \%$ over time, while that of sheep and goats increased by $10.1 \%$ and $11.4 \%$ respectively. Sheep are more common than other livestock - $2.4 \%$ more than goats and $10.4 \%$ more than cattle. Compared to some part of Africa, goats are more common. For instance, Anteneh et al. (2004) studied goat production and livelihood systems in Sekhukhune district of the Limpopo province in South Africa and maintained that goats are more common than other livestock - twice as many as sheep and almost three times as many as cattle. Table 5 shows the result of the pairwise t-test for the study. It is stated as follows: $\mathrm{t}(5)=-6.000, \mathrm{p} 0.05, \mathrm{CI}_{0.95}-20.02$, 8.02. This indicates that there is no significant difference between the livestock types in the 1970s and 2000 s as observed during the study period. 


\begin{tabular}{|c|c|c|c|c|c|}
\hline \multirow{2}{*}{$\begin{array}{l}\text { Type of } \\
\text { livestock }\end{array}$} & \multicolumn{2}{|c|}{ Reared in the $1970 \mathrm{~s}$} & \multicolumn{2}{|c|}{ Reared in the $2000 \mathrm{~s}$} & \multirow{2}{*}{$\begin{array}{l}\text { Difference } \\
(\%)\end{array}$} \\
\hline & $\begin{array}{l}\text { Number of } \\
\text { respondents }\end{array}$ & Percentage & $\begin{array}{l}\text { Number of } \\
\text { respondents }\end{array}$ & Percentage & \\
\hline Cattle & 178 & 39.6 & 201 & 44.7 & 5.1 \\
\hline Sheep & 202 & 44.9 & 248 & 55.1 & 10.2 \\
\hline Goats & 186 & 41.3 & 237 & 52.7 & 11.4 \\
\hline
\end{tabular}

Table 5: Pairwise t-test for livestock types in the 1970s and 2000s in the Sokoto-Rima River Basin

\begin{tabular}{llllllll}
\hline $\begin{array}{l}\text { Livestock } \\
\text { Rearing } \\
\text { Method }\end{array}$ & \multicolumn{9}{c}{$\begin{array}{l}\text { Paired Differences 95\% } \\
\text { Confidence Interval of } \\
\text { the Difference }\end{array}$} \\
\hline & Mean & Std. Dev. & Lower & Upper & T-Value & df & Significant (2-tailed) \\
\hline Livestock types & -6.00 & 15.38397 & -20.22780 & 8.22780 & -1.032 & 6 & 0.342 \\
\hline
\end{tabular}

Conclusion: The study has shown that livestock rearing varied from 10.2 to $13.6 \%$ for only cattle, sheep and goats, and 3.6 to $20.2 \%$ for livestock combination in the 1970 s while in the $2000 \mathrm{~s}, 10.4$ to $11.6 \%$ reared each of the livestock solely and 2.9 to $26 \%$ for the combinations. The rearing of cattle only, sheep and goats, and cattle, sheep and goats together increased by $0.2 \%$ to $6.6 \%$ while sheep only, goats only, cattle and sheep, and cattle and goats decreased by $0.3 \%$ to $2 \%$. The total of cattle, sheep and goats has increased by $5.1 \%, 10.1 \%$ and $11.4 \%$ respectively over time. Sheep were $2.4 \%$ more than goats and $10.4 \%$ more than cattle. Livestock rearing has increased by $9.3 \%$ over time

\section{REFERENCES}

Adejuwon, JO (2012). An Assessment of the Effect of Climate Variability on Selected Agricultural Practices and Yields in Sokoto-Rima River Basin, Nigeria. Unpublished PhD. Thesis, Obafemi Awolowo University, Ile-Ife, p. 312

Adejuwon, JO (2015). An assessment of the changing pattern in the choice of vegetable varieties in Sokoto-Rima River Basin, Nigeria: Pepper. Int. J. Ecol. Env. Studies, 3(2): 7-15.

Adejuwon, JO (2016). Effect of Climate variability on school attendance: A case study of Zamfara State in the Semi-arid zone of Nigeria. Weather, 71 (10): 248-254.

Adejuwon, JO (2018) Assessment of the changing pattern in Maize cultivation in Sokoto-Rima River Basin, Nigeria. J. Appl. Sci. Environ. Manage. 22 (9): 1433-1437.

Anteneh, NT; Mekala, DG; Mnisi, PE; Mukisira, C; Muthui, M; Murungweni, C; Sebitloane, O (2004). Goat Production and Livelihood Systems in Sekhukhune District of the Limpopo Province. International Centre for development oriented
Research in Agriculture (ICRA), Working Document Series 118, South Africa

Emielu, SA (2000). Senior Secondary Geography. Geographical Bureau Nigeria Limited, Ilorin. Pp 71-72.

Fafchamps, M; Udry, C; Czukas, K (1998). Drought and savings in West Africa: Are livestock a buffer stock?, Journal of Development Economics, Vol. 55 , pp. 273-305.

Iliya, MA; Kwabe, SA (2000). Kebbi State. In A.B Mamman, J.O Oyebanji, S.W. Petters (Eds): Nigeria: A People United, A Future Assured. Survey of States (Millenium Edition). Vol. 2. Federal Ministry of Information, Abuja, Nigeria, 305-320

International Union for Conservation of Nature (IUCN) (2010), "Building climate change resilience for African livestock in sub-Saharan Africa - World Initiative for Sustainable Pastoralism", (WISP): a program of IUCN - The International Union for Conservation of Nature, Eastern and Southern Africa Regional Office, Nairobi, March 2010, viii + 48pp.

Koubková, M; Knížková, I; Kunc, P; Härtlová, H; Flusser, J; Doležal, O (2002). Influence of high environmental temperatures and evaporative cooling on some physiological, haematological and biochemical parameters in high-yielding dairy cows. Czech Journal of Animal Science 47: 309318.

Mamman AB (2000a). Sokoto State. In A.B Mamman, J.O Oyebanji, S.W. Petters (eds). Nigeria: A People United, A Future Assured. Survey of States (Millenium Edition), Vol. 2. Federal Ministry of Information, Abuja, Nigeria. pp 499514. 
Mamman, AB (2000b). Zamfara State. In A.B Mamman, J.O Oyebanji, S.W. Petters (eds). Nigeria: A People United, A Future Assured. Survey of States (Millenium Edition), Vol. 2. Federal Ministry of Information, Abuja, Nigeria. pp 547-560.

Parons, DJ; Armstron, AC; Turnpenny, JR; Matthews, AM; Cooper, K; Clark, JA (2001).

"Integrated models of livestock systems for climate change studies", Global Change Biology, Vol. 7, pp. 93-112.

Pica-Ciamarra, U; Tasciotti, 1; Otte, J; Zezza, A (2011). "Livestock assets, livestock income and rural households Cross-country evidence from household surveys", ESA Working Paper No. 1117; Food and Agriculture Organization of the United Nations, 2011

Resources Inventory and Management Limited (RIM) (1992). Nigerian Livestock Resources, Volume I: Small Ruminants. Report by Resources Inventory and Management Limited, U.K. to FDLPCS, Abuja, Nigeria

Sejian, V (2013) Climate Change: Impact on production and reproduction, adaptation mechanisms and mitigation strategies in small Ruminants: A Review. The Indian Journal of Small Ruminants, 19(1): 1-21

Seo, N; Mendelsohn, R (2008). "Animal husbandry in Africa. Climate change impacts and adaptation" African Journal of Agricultural and Resource Economics, 2(1): 65-82.

Singh, SV; Upadhyay, RC; Ashutosh; Hooda, OK; Vaidya, MM (2011). Climate change: impacts on the reproductive pattern of cattle and buffaloes: A review. Wayamba Journal of Animal Science, WJASID 1322125457
Thornton, P; Herrero, M; Freeman, A; Mwai, O; Rege, E; Jones, P; McDermott, J (2007). Vulnerability, climate change and livestock - Research opportunities and challenges for poverty alleviation. SAT eJournal 4 (1), 1-23.

UNFCCC (2007).Climate Change Impacts, Vulnerabilities and Adaptation in Developing Countries.

http://nufccc.in/resources/docs/publications, 5/5/2012.

Usman Danfodiyo University Consultancy Services (UDUCONSULT) (1990). A Survey of Livestock Potentials in Sokoto State. Gamji Bank of Nigeria Limited Project. Preliminary Report submitted to Coopers and Libran Associates.

Wilson, RT (1987). Livestock production in central Mali: environmental factors affecting weight in traditionally managed goats and sheep. Animal Production 45: 223-232

Wilson, RT; Durkin, JW; (1983). Livestock production in central Mali: reproductive components in traditionally managed sheep and goats. Livestock Product. Sci. 19:523-529.

Wilson, RT; Saryers, AR (1987). Livestock production in central Mali: effects of climatic variables on the period of birth and on litter size in traditionally managed goats and sheep. Agric. Forest Meteorol. 40: 31-36. 